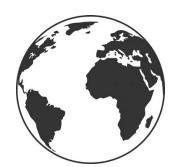

cambridge.org/enc

\section{Irrigation Water Pricing in India as a Means to Conserve Water Resources: Challenges and Potential Future Opportunities}

\author{
Sriroop Chaudhuri and Mimi Roy
}

Center for Environment, Sustainability and Human Development (CESH), Jindal School of Liberal Arts and Humanities, OP Jindal Global University, Sonipat, Haryana, 131001, India

\section{Comments}

Cite this article: Chaudhuri S, Roy M (2019) Irrigation Water Pricing in India as a Means to Conserve Water Resources: Challenges and Potential Future Opportunities. Environmental Conservation 46: 99-102. doi: 10.1017/S037689291800036X

Received: 29 March 2018 Accepted: 31 August 2018

First published online: 9 October 2018

\section{Keywords}

groundwater depletion; irrigation water pricing; water value-cost; volumetric pricing; political dynamics; water conservation; farmers' willingness

Author for correspondence: Prof. Sriroop Chaudhuri, Email: schaudhuri@jgu.edu.in

\section{Introduction}

Groundwater forms the mainstay of agricultural irrigation in India, supporting over $50 \%$ of the total irrigated area and $70 \%$ of crop production, providing livelihood opportunities to half the population (World Bank 2010). But uncontrolled overuse of groundwater resources has accelerated widespread water-table declines (Rodell et al. 2009). Globally, groundwater depletion rates in India are now the highest (Aeschbach-Hertig \& Gleeson 2012). Depletion of groundwater reserves has raised critical concerns over sustainable irrigation supply, food security and ecosystem services loss. Instituting a water-pricing framework for irrigation could help to regulate groundwater use and conserve dwindling water reserves. The need becomes more compelling as over 250 districts in 11 states are prone to recurrent drought events (Table 1), leading to acute water scarcity, crop damage, economic losses and livelihood crises. Here, we summarize the current irrigation water-pricing practices in India in an attempt to understand the key deterrents to effective water resources management and to outline potential future directions.

There is as yet little effort to price groundwater, even though it furnishes the bulk of irrigation water demand. Land area under groundwater-sourced irrigation has soared from c. $29 \%$ of nationwide net irrigated area in 1960-1961 to c. 62\% in 2012-2013 (GoI 2014), while surface-sourced irrigation dropped from c. $42 \%$ to $23 \%$. Several factors contributed to this 'transition': (1) growth in rural population density; (2) boom in smallholder farms (<2 ha); (3) increased demand for year-round, on-demand water supply; (4) inefficient institutional governance (incomplete projects, poor maintenance of infrastructure, low public investment) of canal-sourced irrigation; (5) energy subsidies to pump groundwater; and (6) new irrigation methods (Amarasighe et al. 2009). However, water pricing still mostly applies to canal-sourced systems. Even then, there is considerable regional variation in levying the rates (Table 1) (CWC 2017). In the states of Haryana, Rajasthan and Punjab, where water-level declines are greatest in India, irrigation water pricing levels are among the lowest for paddy and do not apply to groundwater. Spatially uniform rates (maximum $=$ minimum) apply to wheat and sugarcane in 14 and 9 states, respectively (Table 1). In Punjab, Himachal Pradesh and Tripura, spatially uniform and flat rates apply to all three crops. In Goa, Gujarat, Jammu and Kashmir, Karnataka, Assam, Maharashtra and Orissa, the same applies to two varieties. Certain states have no pricing system at all.

Ideally, irrigation water pricing should be keyed to: (1) type of crops (food vs. cash) and crop water requirement; (2) type of irrigation method (gravity, lift, drip/sprinkler); (3) land character (wet vs. dry); (4) financial capacity of farmers; (5) scale of irrigation project (large, medium, small); and (6) water resources vulnerability (Kulkarni 2007). However, there is little consistency in application of these factors. A prime issue in implementing a robust water pricing system in India is the lack of periodic revisions of rates (Table 1). Revisions should be based on regional hydro-climatic traits, live reservoir capacity and recharge pattern. In addition, distinctions have to be made between irrigation and non-irrigation usage. Most irrigation projects produce diminishing returns (Sindhu 2010). Optimum levels of irrigation water pricing rates should be, according to the Irrigation Commission of India, 5\% of gross income for food crops and $12 \%$ for cash crops. In practice, water fee receipts have only been $2.9 \%$ at most for both types. Percentage recovery of working expenses of irrigation projects via irrigation water tariffs ('gross receipt') has been variable but consistently poor over time nationwide ( $<20 \%$ recovery) as well as for certain states ( $<30 \%$ recovery) known for appalling groundwater depletion (Fig. 1) (CWC 2017). In a vicious cycle, poor financial recovery leads to poor operation and maintenance of irrigation infrastructure, poor investment in irrigation projects, more economic losses and, eventually, reduced opportunities for implementing irrigation water pricing. 
Table 1. Minimum and maximum irrigation water prices in 29 states in India for paddy, wheat and sugarcane under flow irrigation, and percentages of droughtaffected districts (1 US\$ $\approx 67$ INR). NA = states with no irrigation pricing data or drought-affected districts (source: CWC 2017)

\begin{tabular}{|c|c|c|c|c|c|c|c|c|}
\hline \multirow[b]{3}{*}{ State } & \multicolumn{6}{|c|}{ Crop-specific rates (INR ha-1) } & \multirow[b]{3}{*}{ Year of last revision } & \multirow[b]{3}{*}{$\begin{array}{c}\text { Drought-affected } \\
\text { districts (2015-2016) (\%) }\end{array}$} \\
\hline & \multicolumn{2}{|c|}{ Paddy } & \multicolumn{2}{|c|}{ Wheat } & \multicolumn{2}{|c|}{ Sugarcane } & & \\
\hline & Maximum & Minimum & Maximum & Minimum & Maximum & Minimum & & \\
\hline Punjab & 123 & 123 & 123 & 123 & 123 & 123 & 1974 & NA \\
\hline Himachal Pradesh & 49 & 49 & 49 & 49 & 49 & 49 & NA & NA \\
\hline Tripura & 312 & 312 & 312 & 312 & NA & NA & NA & NA \\
\hline Goa & 180 & 180 & NA & NA & 360 & 360 & NA & NA \\
\hline Gujarat & 160 & 160 & 160 & 160 & 300 & 300 & 1981 & 15 \\
\hline Jammu and Kashmir & 298 & 298 & 150 & 150 & 298 & 298 & NA & NA \\
\hline Karnataka & 247 & 247 & 148 & 148 & 988 & 988 & 1985 & 93 \\
\hline Assam & 751 & 281 & 562 & 562 & 222 & 222 & NA & NA \\
\hline Maharashtra & 476 & 119 & 476 & 476 & 6297 & 6297 & 1990 & 78 \\
\hline Orissa & NA & NA & 170 & 170 & 500 & 500 & 1981 & 90 \\
\hline Andhra Pradesh & 494 & 370 & NA & NA & 864 & 864 & 1986 & 77 \\
\hline Arunachal Pradesh & NA & NA & NA & NA & NA & NA & NA & NA \\
\hline Bihar & 247 & 108 & 185 & 138 & 370 & 370 & 1983 & NA \\
\hline Chhattisgarh & 494 & 200 & NA & NA & 741 & 741 & NA & 93 \\
\hline Haryana & 148 & 123 & 123 & 111 & 197 & 172 & 1975 & NA \\
\hline Jharkhand & 217 & 108 & 185 & 138 & 370 & 370 & NA & 92 \\
\hline Kerala & 99 & 37 & NA & NA & NA & NA & NA & NA \\
\hline Manipur & 602 & 305 & 305 & 305 & NA & NA & NA & NA \\
\hline Meghalaya & NA & NA & NA & NA & NA & NA & NA & NA \\
\hline Mizoram & NA & NA & NA & NA & NA & NA & NA & NA \\
\hline Madhya Pradesh & 155 & 85 & 125 & 75 & 960 & 960 & 1992 & 90 \\
\hline Nagaland & NA & NA & NA & NA & NA & NA & NA & NA \\
\hline Rajasthan & 197 & 49 & 148 & 64 & 286 & 103 & 1982 & 58 \\
\hline Sikkim & 100 & 60 & NA & NA & NA & NA & NA & NA \\
\hline Tamil Nadu & 49 & 5 & NA & NA & 55 & 5 & 1962 & NA \\
\hline Telengana & NA & NA & NA & NA & NA & NA & NA & 70 \\
\hline Utter Pradesh & 123 & 37 & 287 & 40 & 474 & 99 & 1983 & 67 \\
\hline West Bengal & NA & NA & 49 & 49 & NA & NA & 1977 & NA \\
\hline
\end{tabular}

\section{Existing Challenges}

A number of mutually reinforcing social and socio-political factors combine to prevent any rational arrangement of irrigation water pricing. These include lack of: (1) farmers' participation in the irrigation project design or implementation; (2) transparency between farmers and regional irrigation management authorities, leading to communication gaps and farmers' unwillingness to comply with water-pricing systems; (3) penalties for project personnel who fail to provide desired level of services; (4) user penalties for non-payment (water officials are often bribed to avoid payment or penalty); (5) transparency in water fee collection (often, the water bills are fabricated); and (6) agro-power subsidies (pump at will). Also, rampant water piracy (diverting irrigation water supply for other uses) hinders accurate estimation of irrigation water use. Another issue is poor irrigation service delivery - time mismatch between times of need (e.g., peak cropping season) and when irrigation services are available. Duration of services adds to the concern too, both within a day and within the cropping season as a whole. In addition, the volume of water necessary and that which is actually delivered though irrigation services often do not tally.

An overriding factor that constrains opportunities for irrigation water pricing is the strong political entrenchment of agrarian policies (Narayanmoorthy 2011). For example, providing irrigation users with agro-power subsidies has been heavily criticized as it provides farmers free rein to pump groundwater. In Haryana, Punjab, Rajasthan and Uttar Pradesh, unconstrained irrigation pumping, fuelled by subsidized agro-power services, has only exacerbated groundwater depletion. This negatively impacts agricultural production, yet agropower subsidies continue to remain in place as they are exploited by political parties to gain local electoral control. The situation is the same with water pricing; farmers consider access to groundwater as a fundamental right (Shiferaw et al. 2003) and aquifers as open-access resources. Tube wells are often installed adjacent to recharge locations to maximize irrigation, which aggravates groundwater depletion; they mark a confluence of a lack of environmental awareness and the selfish tendency of individuals to maximize personal benefits (Shah 2009). This elevates risks of social conflicts and inequity, which political parties exploit. In Indian politics, the final outcome of any economic optimization of public resources is determined by interactions between politicians, bureaucrats, stakeholders and their relative bargaining powers. Challenges magnify where political interests conflict. Thus, even though water pricing is likely to curb over-extraction (Mukherji et al. 2009), efforts are thwarted by regional politics. Such political interference is a global phenomenon. For example, groundwater pricing following the Water Framework Directive (WDF 2000/60/EC) met with opposition in multiple EU-27 nations, as farmers viewed it as an impediment to agrarian expansion opportunities and used their political lobbies to repeal it (Levidow et al. 2014). 


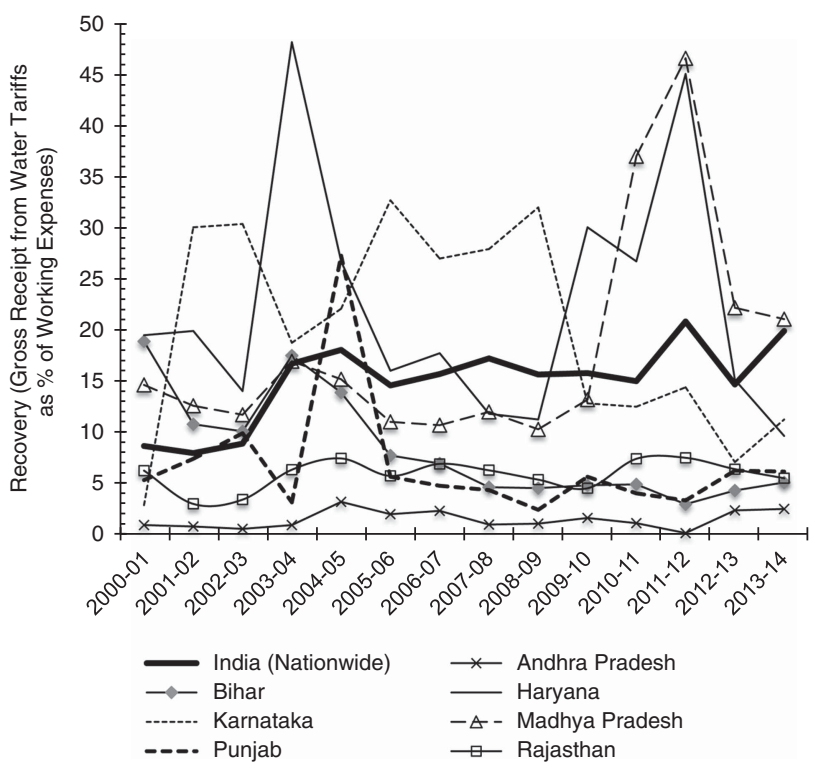

Fig. 1. Financial recovery (gross receipt expressed as percentage of working expenses of corresponding irrigation project) between the 2000-2001 and 2013-2014 periods in India and selected states where groundwater depletion has been the highest in the country (source: CWC 2017). In Punjab, Rajasthan and Haryana, groundwater development is already over $100 \%$, indicating future risks of irrigation water scarcity. In Madhya Pradesh, Karnataka and Andhra Pradesh, over three-quarters of districts are drought affected.

\section{Future Opportunities}

\section{Cost-Value Accounting}

A sound water-pricing system should recognize both: (a) cost of irrigation supply; and (b) value of water use in rural livelihoods (Zoumides \& Zachariadis 2009). The cost component encompasses irrigation water supply services, the operation and maintenance of irrigation infrastructure and capital inflation or depreciation, among others. However, it also includes costs of the creation of livelihoods, equivalent energy costs for pumping and costs of socio-environmental externalities (monetary equivalent of human health damage due to water pollution). The value component looks past the immediate use (irrigation) and includes all indirect uses as well, such as gains from irrigation return flow, cultural/aesthetic (intrinsic) values of water and the irrigation scheme's contribution, for example, to rural poverty alleviation schemes and ensuring food security. The overall idea is to understand the diverse role water plays in rural livelihoods. Water supplied to farmers as part of irrigation projects is not just constrained to irrigation alone, but is used for domestic purposes, running local business, maintaining rural healthcare facilities and so on. A robust water-pricing system would quantify the apportionment of water by sector and maintain an open-sourced, digital geodatabase for in-depth and periodic econometric appraisal. Such a database does not exist.

\section{From Area to Volume}

In India, irrigation water pricing is mostly based on crop area (Sindhu 2010), which is both labour-intensive and prone to error. Moreover, as it sets arbitrary charges on irrigation water use, agrarian communities do not welcome it. One way around the problem is to introduce a volumetric system using in-built automatic metering devices to charge for actual volume used (Kulkarni 2007). Automation increases accuracy and billing efficiency, which enhance farmers' irrigation opportunities. Unlike the area-based 'approximation', it allows flexibility in crop choices (allows a shift to high-value crops) and permits actual payments to vary by crop (Shiferaw et al. 2003). However, a challenge to such automation is the lack of an adequate technology support system and financing to install electronic metering devices in a country as vast as India. Last but not least, risks of tampering with water meters (wherever installed) and of stealing of electronic equipment add to the challenge of implementing an automated water-pricing system.

\section{...But Not Least}

However, farmers should be included in price decision-making itself to dispel misconceptions and build confidence among stakeholders. Farmers should be charged for the actual volume of water used in irrigation (spatially optimized even within a state) rather than a flat (or uniform) amount with automated metering systems. Of particular interest should be the real-time monitoring of vulnerable regions, those that are drought prone and where there are high risks of crop failure. To that end, the contribution of groundwater to the irrigation sector should be explicitly acknowledged in policy frameworks. State-wise groundwater situations (e.g., depletion rates) and irrigation abstraction patterns should be assessed and priced accordingly. But before any of this can occur, there is a dire need to seek policy avenues to keep political entrenchment to a minimum.

Acknowledgements. We thank the Center for Environment, Sustainability and Human Development (CESH), OP Jindal Global University, Sonipat, Haryana, India, for supporting the study.

\section{References}

Aeschbach-Hertig W, Gleeson T (2012) regional strategies for the accelerating global problem of groundwater depletion. Nature Geosciences 5: 853-861.

Amarasighe UA, McCornick P, Shat TA (2009) Projections of irrigation water demand in India: what do recent trends suggest? International Journal of River Basin Management 7(2): 157-166.

CWC (2017) Pricing of Water in Public Systems in India. New Delhi, India: Information System Organization, Water Planning and Projects Wing, Central Water Commission.

GoI (2014) Directorate of Economics and Statistics, Department of Agriculture and Cooperation, Ministry of Agriculture, Government of India. Irrigation. URL http://www.indianstatistics.org/irrigation.html

Kulkarni SA (2007) Volumetric pricing of irrigation water in India: experiences and lessons learned. Presented at: 4th Asian Regional Conference and 10th International Seminar of Participatory Irrigation Management, Tehran, Iran, 2-5 May 2007.

Levidow L, Zaccaria D, Maria R, Vivas E, Todorovi M, Scardigno A (2014) Improving water-efficient irrigation: prospects and difficulties of innovative practices. Agricultural Water Management 156: 84-94.

Mukherji A, Das B, majumder N, Nayak NC, Sethi RR, Sharma BR, Banerjee PS (2009) Metering of agricultural power supply in West Bengal: who gains and who loses? Energy Policy 37(12): 5530-5539.

Narayanmoorthy A (2011) Development and composition of irrigation in India: temporal trends and patterns. Irrigation and Drainage 60: 431-445.

Rodell M, Velicogna I, Famiglietti JS (2009) Satellite-based estimate of groundwater depletion in India. Nature 460: 999-1002.

Shah T (2009) Climate change and groundwater: India's opportunities for mitigation and adaptation. Environmental Research Letters 4: 035005. 
Shiferaw BA, Wani SP, Nageswara Roa GD (2003) Irrigation Investments and Groundwater Depletion in Indian Semi-Arid Villages: The Effect of Alternative Water Pricing Regimes. Working Paper Series No. 17. Patancheru, India: India Crops Research Institute of the Semi-Arid Tropics. Sindhu JS (2010) Water pricing and sustainable surface water irrigation management. Indian Journal of Science and Technology 3(8): 932-936.
World Bank (2010) Deep Wells and Prudence: Towards Pragmatic Action for Addressing Groundwater Overexploitation in India. Washington, DC, USA: World Bank.

Zoumides C, Zachariadis T (2009) Irrigation water pricing in Southern Europe and Cyprus: the effects of EU Common Agricultural Policy and the Water Framework Directive. Cyprus Economic Policy Review 3(1): 99-122. 